\title{
The effectiveness of online Mathematics learning
}

\author{
Akhsanul In'am ${ }^{1^{*}}$ and Siti Hajar ${ }^{2}$ \\ ${ }^{1}$ Universitas Muhammadiyah Malang \\ ${ }^{2}$ Madrasah Tsanawiyah Negeri 1 Malang \\ *Corresponding author: akhsanul@umm.ac.id
}

\author{
KEYWORDS \\ Activity \\ Learning effectiveness \\ learning evaluation \\ responses
}

\begin{abstract}
This study aims to analyze the effectiveness of online Mathematics learning. It employed a qualitative research design with a case-study technique. Subjects of this study were 7 th graders from five different classes at Madrasah Tsanawiyah Negeri 1 Malang. Data collection methods were observations, documents of zoom learning, and interviews with student guardians. The obtained data were analyzed through data description. Results showed that there were disturbances in the online learning activities. Among the problems were student punctuality and unstable internet connection activities. During the online learning, most students could not follow the lesson very well, and only a few responded to the teachers. There were also problems in students' monitoring and evaluation. These aspects of learning activities, students' responses, and monitoring and evaluation implied that online Mathematics learning was ineffective.
\end{abstract}

(c) The Author(s) 2021

\section{INTRODUCTION}

The current Covid-19 pandemic has been around for more than 1.5 years and has changed our political, economic, social, and cultural lifestyle, as well as security. There have also been major changes in the field of trading where it used to be carried out physically, now has shifted into online. Our usual face-to-face purchasing activities now seem less safe than online shopping (Agustino, 2020; Setiati \& Azwar, 2020; Syafrida \& Hartati, 2020).

Indonesia, a country where community activities are strongly characterized as a nation, has also undergone drastic changes. Communal activities such as social gatherings and congregational prayer are now carried out virtually. Meetings and discussions in the family or office are also carried out virtually (Ahmady et al., 2020; Syafrida \& Hartati, 2020).

Indonesians' habits to relieve fatigue and doing recreational activities cannot be carried out optimally. Such activities have turned into individual activities. Some find leisure in gardening, some in writing, and some do other things as long as the activity could ward off fatigue.

In education, learning that was usually conducted faceto-face at school was forced to be conducted virtually. Much research on the implementation of online learning has been conducted, and several problems emanated, including 1) unstable internet connection (even no network); 2) minimum student understanding on the subject matter; 3) evaluation of student learning outcomes (Bibi \& Jati, 2015; Kliziene et al., 2021; Phoong et al., 2020). When online learning is implemented, students faced difficulties in following the given lesson (Achdiyat \& Andriyani, 2016; Aluja-Banet et al., 2019; Bibi \& Jati, 2015). Among the reasons are students' difficulties to wake up early, lack of parental support where they could not supervise their children during online learning activities.

Meanwhile, teachers also faced difficulties where they could not keep up with the online learning system properly (Aluja-Banet et al., 2019; Phoong et al., 2020; Zeinali et al., 2020). Some teachers needed help in operating digital facilities, resulting in minimum learning implementation. For instance, teachers faced problems in sending and receiving online assignments.

It is obvious that there are too many problems with online learning activities. Ideally, learning should be meaningful with active interaction between teachers and students, although it is conducted online. Especially in learning Mathematics, direct interaction between teachers and students is critical because prompt feedback can be given, which online learning cannot accommodate.

Besides content knowledge, learning Mathematics require problem-solving skills. Polya noted four stages in Mathematics problem solving, including understanding, planning, implementing and re-checking. The stage of understanding is obtained by students from the teachers, both through direct and online learning, as well as planning. However, when students have to perform problem-solving, satisfactory results can only be attained through direct face-to-face learning. In face-to-face learning, teachers can check how the students are doing and can assist when there are problems. Likewise, the stage of re-checking can be performed properly through direct learning. Hence, this study aims to explore Mathematics online learning along with student responses. It also investigates the extent to which students understand the learning material through 
the three aspects of indicators of the effectiveness of Mathematics online learning.

\section{LITERATURE REVIEW}

Among the attempts to determine the success of an activity is by looking for its effectiveness (In'am, 2017). Concerning online learning activities, a study is critical to determine the extent to which the success of an online learning activity can take place in accordance with the predetermined plan. The effectiveness of learning activity can be measured through three aspects, namely: 1) student activities during learning, which student achievement can be measured against the learning plan; 2) students' responses throughout the online learning activity; and 3) student learning outcomes, which can be measured following the criteria of the minimum score (Christina \& Kristin, 2016; In'am, 2017).

\subsection{Student activity}

Virtual learning has resulted in various online learning activities. Online interaction between teachers and students has brought the epitome of close to the eyes but far within reach. This condition has impacted the implementation of student activities.

Learning activities are one's actions to achieve the desired goals of education. Effective learning can be assessed through student activities. In this case, students' actions are closely related to their behaviours, opinions, and interests during learning (Mawaddah \& Maryanti, 2016).

Student learning activities include their actions in observing pictures. Their ability can be seen from oral activities, including giving opinions and suggestions, asking questions, and discussion. During the Covid-19 pandemic, students' activity can be observed through their virtual involvement, including crafting and posing questions, discussion, and expressing opinions. Hence, learning activities includes student activities in visual, listening, writing, and mental activities.

\subsection{Student responses}

Attitudes that show students' active participation can be considered as student learning responses. Virtual learning has changed the forms of responses that can be observed directly into virtual observation. This calls for a comprehensive teacher ability in analyzing student responses by taking into account the context and surrounding environment.

There are three aspects to analyze student responses, including 1) cognitive, which relates to students' understanding and skills; 2) affective, which relates to students' emotions, interests, attitudes, and judgment; 3) conative, which relates to students' real behaviour, such as actions or changes (Zulkarnain \& Amalia, 2016).

It is also said that students' responses are divided into two, namely: 1) positive responses, which are marked by an attitude of accepting, responding, showing attention, and understanding; and 2) negative responses, which are characterized through the attitude of resistance, denial, avoidance, and disrespect. At the time of learning, student responses will increase when they have an interest in getting good grades (Lestari, 2015).
In conclusion, students' responses reflect their behaviour and interest in learning, which they actively involve and respond to teachers during learning.

\subsection{Student learning achievement}

Student learning achievement is attained after a specific amount of time and learning experience. It also refers to changes in student behaviour upon completion of a lesson. Successful learning achievement is characterized by students' improvement in understanding of a lesson (Bibi \& Jati., 2015; Andriyani \& Rasto, 2019).

Satisfactory learning outcomes take place when the learning objectives are met by both students and teachers. It indicates that teachers' classroom practices are good, and vice versa if students' learning achievement is not satisfactory. Low learning outcomes also implies that the learning process is ineffective (Achdiyat \& Andriyani 2016).

In so doing, teaching and learning activities do not solely cover the material transfer but also provide monitoring and evaluation. Both processes aim to study the level of student outcomes after learning (Firmansyah, 2015).

\section{METHOD}

This study employed a qualitative research design with a case study technique. Subjects were 7 th graders from five different classes at Madrasah Tsanawiyah Negeri (MTsN) 1 Malang. This study investigated the implementation of online Mathematics learning in semester 2 of the 2020/2021 academic year. Different from public schools, MTsN 1 Malang separates the students into male classes and female classes. Subjects of this study were three female classes and two male classes.

The data collection process included observations during the online learning, interviews with students' guardians, and documents in the forms of daily exam results and final term exam results. The obtained data were analyzed descriptively through the explanation of observation field notes and ethical presentation of the interview transcription.

\section{RESULTS AND DISCUSSION}

\subsection{Student activity}

Mathematics subject at MTsN 1 Malang in 2020/2021 academic year was carried out virtually via Zoom. Meanwhile, the assignments and exams were distributed through an elearning program developed at the school. The five classes (Class A, B, C, D, and E) have relatively similar characteristics. Class B and D were all-male classes, and A, C, and D were all-female classes.

Observation results showed that only one person in Class A was less involved. A confirmation via What's App with the student's parents showed a lack of parental supervision during the learning process. Three other students were monitored to perform low learning motivation because of less time management ability between studying and other activities.

In regards to learning motivation, two students in classes B and C were found less motivated, while only a small number of students in Class D were actively involved. Ten students were monitored actively in learning activities. However, students of Class E (all-female class) were reported to be actively involved during learning. 


\subsection{Student responses}

It is stated earlier that the observation of student attitudes during learning could help identify students' involvement. The observation results indicated that students of Class E (all-female class) showed a very good response during online learning. Meanwhile, Class A and C (all-female class) showed fairly good responses.

Class B and D, where all students were males, showed poor responses. Hence, the researcher interviewed student guardians. Some parents stated that they could not supervise home learning because they had to work.

There was one particular problem where a student did neither show good response nor learning motivation. The school's guidance and counselling staff handled this student, yet his learning motivation did not increase. Interview results with the parents showed that: 1) the student could not manage time well during home learning, and 2) boredom because of staying home daily and less social interaction.

\subsection{Learning achievement}

Learning achievement measures learning effectiveness. MTsN 1 Malang belongs to the group of favourite schools in the city where students' minimum score criteria are quite high. The criterion for Mathematics in MTsN 1 Malang is 80. Based on the tests, the daily exams are also used as summative exams. The results showed that most students achieved learning outcomes below the minimum score criteria.

Out of 27 students in Class A, four students scored according to the minimum criteria. In Class B, nine students out of 30 students scored above the minimum criteria. Out of 27 students in Class C, 21 students scored under the minimum criteria, leaving only nine students scored above the minimum criteria. In Class D, only ten students (out of 30 students) scored above the minimum criteria. Last, out of 28 students in Class E, only 12 students scored above the minimum criteria. These findings showed that the majority of students achieved below the minimum score criteria.

This finding concurs with Phoong and colleagues (2020), who stated that virtual learning might not be effective due to several factors. Also, evaluations during virtual learning were inaccurate where a refined policy regarding the implementation of virtual learning is needed (Kabir, 2020; Martín et al., 2021). The findings of this study follow research by Aluja-Banet and colleagues (2019), who stated that student learning motivation during the Covid-19 pandemic was low.

\section{CONCLUSION}

From the three aspects that determined student learning effectiveness, it can be concluded that online Mathematics learning for all-female classes were fair. Meanwhile, all-male classes were poor. Results of students' responses showed similar findings unless one particular class was categorized good, while the other four classes are fair.

Based on the learning achievement, students' exam scores showed that there was only one class categorized as good, in which all students are female. Meanwhile, the other four classes showed fair achievement. Taken together, online Mathematics learning in MTsN 1 Malang was categorized as ineffective.

\section{REFERENCES}

Achdiyat, M., \& Andriyani, F. (2016). Hasil Belajar Matematika Ditinjau dari Model Pembelajaran Teams Assisted Individualization (TAI). Formatif: Jurnal Ilmiah Pendidikan MIPA, 6(3), 246-255. https://doi.org/10.30998/formatif.v6i3.996

Agustino, L. (2020). Analisis Kebijakan Penanganan Wabah Covid-19: Pengalaman Indonesia. Jurnal Borneo Administrator, 16(2). https://doi.org/10.24258/jba.v16i2.685

Ahmady, S., Shahbazi, S., \& Heidari, M. (2020). Transition to Virtual Learning during the Coronavirus Disease2019 Crisis in Iran: Opportunity or Challenge? Disaster Medicine and Public Health Preparedness, 14(3). https://doi.org/10.1017/dmp.2020.142

Aluja-Banet, T., Sancho, M. R., \& Vukic, I. (2019). Measuring motivation from the Virtual Learning Environment in secondary education. Journal of Computational Science, 36. https://doi.org/10.1016/j.jocs.2017.03.007

Bibi, S., \& Jati, H. (2015). Efektivitas model blended learning terhadap motivasi dan tingkat pemahaman mahasiswa mata kuliah algoritma dan pemrograman. Jurnal Pendidikan Vokasi, 5(1), 74. https://doi.org/10.21831/jpv.v5i1.6074

Christina, L. V., \& Kristin, F. (2016). Efektivitas Model Pembelajaran Tipe Group Investigation (Gi) Dan Cooperative Integrated Reading and Composition (Circ) Dalam Meningkatkan Kreativitas Berpikir Kritis Dan Hasil Belajar Ips Siswa Kelas 4. Scholaria: Jurnal Pendidikan Dan Kebudayaan, 6(3), 217. https://doi.org/10.24246/j.scholaria.2016.v6.i3.p217230

In'am, A. (2017). Efektivitas Model Pembelajaran Matematika berbasis Metakognitif. 21(April), 1-12.

Kabir, M. R. (2020). Impact of faculty and student readiness on virtual learning adoption amid Covid-19. Revista Internacional de Educacion Para La Justicia Social, 9(3).https://doi.org/10.15366/RIEJS2020.9.3.021

Kliziene, I., Taujanskiene, G., Augustiniene, A., Simonaitiene, B., \& Cibulskas, G. (2021). The impact of the virtual learning platform eduka on the academic performance of primary school children. Sustainability (Switzerland), 13(4). https://doi.org/10.3390/su13042268

Martín, C. T., Acal, C., Honrani, M. El, \& Estrada, Á. C. M. (2021). Impact on the virtual learning environment due to covid-19. Sustainability (Switzerland), 13(2). https://doi.org/10.3390/su13020582

Mawaddah, S., \& Maryanti, R. (2016). Kemampuan Pemahaman Konsep Matematis Siswa SMP dalam Pembelajaran Menggunakan Model Penemuan Terbimbing (Discovery Learning). EDU-MAT: Jurnal Pendidikan Matematika, 4(1). https://doi.org/10.20527/edumat.v4i1.2292

Phoong, S. Y., Phoong, S. W., \& Phoong, K. H. (2020). The effectiveness of frog virtual learning environment in teaching and learning mathematics. Universal Journal of Educational Research, 8(3 B). https://doi.org/10.13189/ujer.2020.081502

Setiati, S., \& Azwar, M. K. (2020). COVID-19 and Indonesia. Acta Medica Indonesiana, 52(1).

Situmorang, A. S. (2016). Efektivitas Strategi Pembelajaran Ekspositori Terhadap Pemahaman Konsep Matematika. Journal of Chemical Information and Modeling, 53(9), 16891699.https://doi.org/10.1017/CBO9781107415324.004 
Syafrida, S., \& Hartati, R. (2020). Bersama Melawan Virus Covid 19 di Indonesia. SALAM: Jurnal Sosial Dan Budaya Syar-I, 7(6).https://doi.org/10.15408/sjsbs.v7i6.15325

Wibowo, A. (2017). Pengaruh pendekatan pembelajaran matematika realistik dan saintifik terhadap prestasi belajar, kemampuan penalaran matematis dan minat belajar. Jurnal Riset Pendidikan Matematika, 4(1), 1. https://doi.org/10.21831/jrpm.v4i1.10066

Zeinali, M., Almasi-Doghaee, M., \& Haghi-Ashtiani, B. (2020). Facing COVID-19, jumping from inperson training to virtual learning: A review on educational and clinical activities in a neurology department. Basic and Clinical Neuroscience, 11(2).https://doi.org/10.32598/bcn.11.covid19.910.2
Zulkarnain, I., \& Amalia Sari, N. (2016). Model Penemuan Terbimbing dengan Teknik Mind Mapping untuk Meningkatkan Kemampuan Pemahaman Konsep Matematis Siswa SMP. EDU-MAT: Jurnal Pendidikan Matematika, 2(2).https://doi.org/10.20527/edumat.v2i2.619 